\title{
Appendix: Research method
}

Data was collected, including interviews and some ethnographic work (participant observation in urban and rural areas within the Green Line) and London and analysed using an interpretivist approach. ${ }^{1}$ Fieldwork was conducted between 2014 and 2016, starting in the aftermath of the Gaza War, until saturation, and I conducted and transcribed the interviews. The interview data, collected through 50 in-depth, semi-structured interviews with hiloni millennials aged 22-39, was analysed in three rounds. First, it was analysed through a modified Stevick-Colaizzi-Keen method for hermeneutic phenomenological analysis. ${ }^{2}$ The purpose of this approach was to aim for resonance, authenticity and credibility - what does it feel like to be millennial and hiloni? ${ }^{3}$

A large sample size for a phenomenological study was chosen to capture diversity across this social group. Further details of the sampling method are below. Interviewees were sought through public advertisement and snowballsampling for hard-to-reach individuals. ${ }^{4}$ They were selected through random-purposeful criterion sampling for age, hiloni identity and gender, with an additional sample to seek maximum variation in political orientation, geographic-origin diversity, class and ethnic origin. ${ }^{5}$ Interviews were carried out past saturation and analysed using a modified Stevick-Colaizzi-Keen method for phenomenological analysis. ${ }^{6}$ In seeking to achieve authenticity and resonance, this phenomenological study does not aim to perfectly mirror hiloni demographics in the Israeli population in its sampling, but nor does it skew to an activist left. Key demographic characteristics of the sample are presented in Tables 14 and 15. This Appendix offers reflection on issues of methodology and what can (and cannot) be gleaned from the sample. Put simply: the book does not aim to define what all hiloni millennials think at all times and in all places, but rather to record and interpret what this sample thought in a historical moment.

Twenty additional interviews were carried out for critical purchase with members of the transitional Generation XY, with traditionist and Orthodox participants, and with members of civil society with a perspective on key issues (mechinot; Jerusalem; the 'fourth stream' movement in secular Judaism). ${ }^{7}$ Interviewing a set of masortim (Mizrahi and Ashkenazi, sabra (born in Israel) and olim (immigrant)) was particularly important for achieving critical purchase on how millennial participants construct the fuzzy boundary between masortim and hilonim, as was the secondary literature on masortim, particularly Yadgar's 2010 book on the subject. ${ }^{8}$ 
Table 14 Demographic characteristics of study

\begin{tabular}{|c|c|c|c|c|}
\hline Gender $(n=94)$ & $61 \mathrm{men}$ & 33 women & & \\
\hline $\begin{array}{l}\text { Ethnicity } \\
(\mathrm{n}=94)\end{array}$ & 64 Ashkenazi & 6 Mizrahi & $\begin{array}{l}24 \text { mixed } \\
\text { heritage }^{a}\end{array}$ & \\
\hline $\begin{array}{l}\text { Political orientation } \\
(\mathrm{n}=94)\end{array}$ & 40 left & 37 centre & 17 right & \\
\hline $\begin{array}{l}\text { Country of birth } \\
(\mathrm{n}=94)\end{array}$ & 70 Israel & $6 \mathrm{FSU}$ & $\begin{array}{l}7 \text { Western } \\
\text { Europe or } \\
\text { Americas }\end{array}$ & $\begin{array}{l}11 \\
\text { unknown }\end{array}$ \\
\hline $\begin{array}{l}\text { Country of residence } \\
\text { at time of research } \\
(\mathrm{n}=94)\end{array}$ & 75 Israel & 16 Europe & $\begin{array}{l}3 \text { North } \\
\text { America }\end{array}$ & \\
\hline $\begin{array}{l}\text { Engaged in political } \\
\text { activism on issues related } \\
\text { to the Occupation at } \\
\text { some point in their lives } \\
(\mathrm{n}=94)^{c}\end{array}$ & 35 activists & $\begin{array}{l}47 \\
\text { non-activists }\end{array}$ & $\begin{array}{l}12 \\
\text { unknown }\end{array}$ & \\
\hline $\begin{array}{l}\text { Military service } \\
(\mathrm{n}=94)\end{array}$ & $\begin{array}{l}88 \text { (men and } \\
\text { women) served } \\
\text { in military }\end{array}$ & $\begin{array}{l}39 \text { (men } \\
\text { and women) } \\
\text { served in } \\
\text { combat units }\end{array}$ & & \\
\hline $\begin{array}{l}\text { Urban/suburban vs. } \\
\text { rural up to age } 18^{d} \\
(\mathrm{n}=54)\end{array}$ & $\begin{array}{l}9 \text { rural (includ- } \\
\text { ing on kibbutzim } \\
\text { and moshavim) }\end{array}$ & $\begin{array}{l}35 \text { urban/ } \\
\text { suburban }\end{array}$ & & \\
\hline Raised inside/outside & 50 inside the & 4 outside the & & \\
\hline Green Line $(\mathrm{n}=54)^{e}$ & Green Line & Green Line & & \\
\hline
\end{tabular}

${ }^{a}$ These are the children of nisuei ta'arovet (mixed marriages between Ashkenazim and Mizrahim, in this case either parents or previous generations). Okun, 'Insight', has argued that this is not a coherent group with a fixed identity. For critical analysis of Zionist racialization and hierarchization of different groups of Jews in the first decades of the state of Israel see Hirsch, 'Zionist Occidentalism'.

${ }^{b}$ Survey participants who were born abroad were required to have lived in Israel for more than eight years since 2005. Additionally, those who lived abroad at the time of the survey were born in Israel and lived there for approximately 20 years.

'This includes left, right and centrist activists, for and against territorial compromise with Palestinians.

${ }^{d}$ Specifying a current location residence in Israel was optional for online survey participants. ${ }^{e}$ Specifying a current location residence in Israel was optional for online survey participants.

Interviews were triangulated and contextualized by an in-depth online survey I conducted with over 40 young hilonim after interviews were complete; adding to questionnaire data obtained from those interviewed for a total of over 90 young hilonim. The purpose of the survey of interviewees was to further contextualize their narratives; surveying a wider sample provided some critical purchase on interview responses. Some of the questions I asked do not exist in public survey data, so a larger sample was a helpful way to 
Table 15 Demographic characteristics: Jewish-Israeli context (percentages)

\begin{tabular}{|c|c|c|c|}
\hline & $\begin{array}{l}\text { Jewish-Israeli } \\
\text { population }\end{array}$ & Hilonim & This study $(\mathrm{n}=94)$ \\
\hline Gender $^{a}$ & $\begin{array}{l}49.4 \text { men } \\
50.6 \text { women }\end{array}$ & Not available & $\begin{array}{l}65.0 \text { men } \\
35.0 \text { women }\end{array}$ \\
\hline Ethnicity $^{b}$ & $\begin{array}{l}\text { 46.0 Ashkenazi } \\
\text { 52.0 Sephardi/Mizrahi } \\
\text { 2.0 Ethiopian }\end{array}$ & $\begin{array}{l}\text { 35.5 Ashkenazi } \\
\text { 22.3 Mizrahi } \\
\text { 21.4 FSU } \\
\text { 20.8 Israeli }\end{array}$ & $\begin{array}{l}\text { 68.0 Ashkenazi } \\
\text { 6.0 Sephardi/Mizrahi } \\
\text { 26.0 mixed heritage }\end{array}$ \\
\hline $\begin{array}{l}\text { Political } \\
\text { orientation }\end{array}$ & $\begin{array}{l}34.4 \text { right } \\
35.7 \text { right of centre } \\
21.6 \text { left of centre } \\
2.3 \text { left } \\
5.9 \text { don't know/decline } \\
\text { to answer }\end{array}$ & $\begin{array}{l}22.4 \text { right } \\
16.7 \text { right of centre } \\
26.8 \text { centre } \\
13.9 \text { left of centre } \\
20.2 \text { left }^{c}\end{array}$ & $\begin{array}{l}18.0 \text { right } \\
39.0 \text { centre (including } \\
\text { centre, right of centre } \\
\text { and left of centre) } \\
43.0 \text { left }^{d}\end{array}$ \\
\hline $\begin{array}{l}\text { Country } \\
\text { of birth }{ }^{e}\end{array}$ & $\begin{array}{l}\text { 76.0 Israel } \\
\text { 17.0 Europe/Americas } \\
\text { 3.0 Asia } \\
\text { 5.0 Africa }\end{array}$ & $\begin{array}{l}\text { 20.8 Israeli } \\
\text { 21.4 FSU } \\
\text { 35.5 Western } \\
\text { Europe/Americas } \\
\text { (Ashkenazi) }\end{array}$ & $\begin{array}{l}\text { 75.0 Israel } \\
\text { 6.0 FSU } \\
\text { 7.0 Western Europe or } \\
\text { the Americas } \\
\text { 12.0 unknown }\end{array}$ \\
\hline $\begin{array}{l}\text { Military } \\
\text { service }^{f}\end{array}$ & $\begin{array}{l}83.0 \text { conscripted at } \\
18 \text { and completed } \\
\text { service (men) } \\
10-20 \text { combat service }\end{array}$ & Not available & $\begin{array}{l}94.0 \text { conscripted at } 18 \\
\text { and completed service } \\
\text { (men and women) } \\
41.0 \text { combat service }\end{array}$ \\
\hline
\end{tabular}

${ }^{a}$ Yaffe, 'Women and Men'. As Chapters 3 and 6 particularly focus on combat service in the IDF, men are disproportionately represented in this study.

${ }^{b}$ The Israeli Central Bureau of Statistics measures ethnicity by place of birth or father's place of birth. Those labelled 'Israeli' were born in Israel and their fathers were born in Israel. My study uses ethnic self-identification.

'Ben-Porat, Synagogue, 48 (survey conducted 2009).

${ }^{d}$ Israel Democracy Institute and Tel Aviv University, Peace Index poll question, March 2017: 'If Israeli elections are held soon, which government will you want to take office after them?'

${ }^{e}$ For the Jewish-Israeli population: Central Bureau of Statistics, Statistical Abstract, 'Jews by Continent of Origin, Sex and Age', 1 September 2016, www.cbs.gov.il/he/publications/doclib/ 2016/2.shnatonpopulation/st02_06x.pdf. For hilonim: Ben-Porat, Synagogue, 48.

'Rates of conscript troops serving in combat units varies over time, based on the IDF's manpower needs. Cohen, 'One in Six'.

gain perspective on interview responses. The survey followed the stage 2 interview questions (see below).

I then did two additional rounds of analysis of interviews using a grounded theory approach, reading and also listening to the interviews again, charting trends within the interview data. ${ }^{9}$ The interviews and survey data were analysed along with authoritative public opinion polls, civil society, governmental and intergovernmental reports, memoirs, Breaking the Silence testimonies and a qualitative textual analysis of three major newspapers with a 
broad readership representing diverse points on the political spectrum (the Ferusalem Post, Haaretz and Yedioth Ahronoth, 2005-16). ${ }^{10}$ Haaretz is typically associated with a leftist readership, including a hiloni one. The other two are associated with a centre-right readership, which includes hilonim. A thorough review of secondary literature (academic research, policy analysis and journalism, both historical and concerning contemporary politics and society in Israel) was used to lend further context, authenticity and credibility to the study. I also benefited from being allowed to 'lurk' long-term on a Google list for Israeli peace NGOs (2015-19) as well as participating in various public discussions and private events in Israel and London.

A critical aspect of studying potential intersections between supposed 'secular' attitudes towards political conflict and 'secular' attitudes towards religion is not to presume a priori that these things actually do intersect or, if they do, that this actually matters on the ground, to wider public opinion or conflict dynamics. In this Jewish-Israeli case, while there is a stereotype that Orthodox and traditionist Israelis hold hawkish views and hilonim hold doveish perspectives, religiosity and politics do not map neatly in practice, with many shades of grey. ${ }^{11}$ Their politics are complex. Hilonim vote and form political alliances across religious sectors, hold a wide variety of attitudes towards the role of Judaism in public life, and, importantly, do not vote exclusively on attitudes towards the conflict. As explained in the Introduction, the very purpose of the book was to keep an open mind about the research question itself.

Interview participants were told prior to interview that they would be asked about two topics: (1) their personal attitudes towards religion on the one hand and (2) their attitudes towards ethnic-religious nationalism in the conflict on the other. A clear benefit of this approach was that it allowed participants to reject the idea that there were any connections between their personal attitudes towards religion and their attitudes to politics, rather than forcing them into an interpretation that these two intersect. Some said their attitudes to religion and politics were related and from an etic (outside) perspective that did indeed seem to be the case. Some said their attitudes were not related but from an etic perspective they were. And, finally, some joked that they would wait to see the results of the research for me to tell them whether their opinions on religion and politics are related or not.

In developing a question schedule, I drew from several resources for inspiration: the qualitative study of political attitudes towards ethno-religious nationalism; recent innovations in the qualitative study of secularity, including Abby Day's 'researching belief without asking religious questions'; ${ }^{12}$ the comparative, mainly experimental literature on studying 'atheists in foxholes'. ${ }^{13}$ I drew early inspiration from Yaacov Yadgar's rich work on masortim, traditionist Jewish-Israelis whose patterns of belief and practice lie on a spectrum with and often overlap those of hilonim, and the work of Charles S. Liebman on secular Judaism. ${ }^{14}$ Later in the project, after data collection, 
I came to recent innovations in the ethnographic study of everyday religion, which further enriched my analysis of the data.

While interviews were fluid, I generally asked questions in three, consecutive phases: (1) life history-type questions to elicit personal history, formative experiences with Judaism and narratives about how attitudes towards religion, nationalism and Jewish tradition or culture have changed over the life course; (2) semi-structured questions about the role of ethno-religious national symbolism in the conflict, with questions about the four case studies; and (3) adapting Abby Day's method of 'researching belief without asking religious questions', semi-structured questions about people's personal philosophies, existential and ethical beliefs and everyday meaning-making practices. An oral history-type approach was chosen for the first stage so as to let participants 'tell their stories' and lead the interview direction. ${ }^{15}$ During the first round of fieldwork it became clear that the second phase would benefit from semi-structured questions to elicit answers about the case studies and help participants articulate their positions in more depth, beyond repeating that day's media headlines. Phases one and three also provided a rapport-building envelope around the second phase, one in which politically sensitive questions were asked about 'security' matters, to facilitate more candid responses. One clear advantage to this three-phase approach was to allow participants to draw or reject my premises or intersections between topics in their own way. A disadvantage was that the interview structure did not provide an instantly graspable 'red thread' for participants. Interviewees were generous in their willingness to follow this experimental approach to research.

Where participants rejected connections I made between topics, such rejections were taken very seriously in the analysis. These narratives also feature in the book. Despite clear strengths of 'insider' or 'partial insider' research, an advantage of fully 'outsider' research is that it allows for a spirit of experimentation, for you to ask about things which may seem silly or obvious to 'insiders' - and along the way, to discover new things.

\section{Contextualizing my interlocutors}

It is worth noting seven important things about those who feature in this book versus what is known about the hiloni population as a whole, across generations. First, the random-purposeful criterion sampling used in this book does not produce results which are equivalent to demographic weighting. This book does not make large claims that 'all hiloni millennials think X'. The purpose of gathering (some) additional statistical data was for me to assess how representative either responses to the survey or interviews were within my group of informants, not within the population as a whole.

Second, while the Jewish-Israeli population is roughly evenly split by gender, the sample in this study comprised two-thirds men and one-third women. As the book's theoretical concern is violence, Chapter 4 focuses on 
combat service in the Israel Defence Forces. Millennials were the first generation of Jewish-Israeli women to serve in combat positions, after legal change in 2000. Women in combat positions were included in the sample to reflect this. However, even among this generation, combat soldiers continue to be disproportionately men. Therefore, the overall sample was weighted to generate enough data on combat service. While men serving in combat units comprise approximately $10 \%-20 \%$ of the general population, they made up $44 \%$ of my interviewees.

Third, in terms of ethnicity, it is worth noting that the percentage of those identifying as both Ashkenazi and hiloni in my sample (68\%) is roughly equivalent to the percentage $(66 \%)$ in the wider Jewish-Israeli population studied in the 2016 Pew survey. The percentage of those identifying as 'Mizrahi' or 'Mixed' in the sample (32\%) is equivalent to those identifying as 'Sephardi/Mizrahi' and hiloni in the Pew sample (32\%). This equivalence may, however, be deceptive, as mixed ethnicity was not provided as an option in the Pew survey. Those identifying as Mizrahim may be under-represented in my sample. This is taken into account analytically, and Mizrahi hiloni voices amplified in the book overall.

Fourth, I conducted all interviews and the survey myself in English, with Hebrew-speaking research assistance at other stages in the research process. The vast majority of my interviewees were sabras who had lived in Israel all their lives, whose first language is Hebrew. I interviewed olim from various regions to capture diversity among hilonim. Still, additional research with non-English-speakers would help to capture more about this demographic group, particularly more diverse class dynamics, as English fluency is often associated with university education or time spent living abroad.

Fifth, while demographic sub-groups are often identified in the text, this is sometimes omitted where it would jeopardize participant anonymity. Differences between sub-groups were taken into account in the analysis. However, it is important to note that trends identified across the cohort transcended sub-groups. This is a key finding for the study. It problematizes popular perceptions of sharp distinctions between Ashkenazi descendants of the veteran generation and Mizrahi, FSU and North American young people.

Sixth, unless otherwise noted, anonymized quotations are representative of a significant trend found across the cohort, across demographic subgroups and political affiliation.

Finally, in terms of political affiliation, those hilonim identifying with the political left comprise a larger part of my survey sample than they did in Ben-Porat's 2009 survey (43\% in my survey versus 20.2\%). Those on the political right, a slightly smaller part (18\% versus $22.4 \%)$. However, those self-reporting in the political centre - comprising those identifying as centre, centre-right and centre-left - are significantly smaller in my survey than in Ben-Porat's (29\% versus 57.4\%). This was taken into account in the analysis. This difference with Ben-Porat's sample may be due to fluctuations in self-identification. It may also be a function of a different electoral context. 
Ben-Porat's survey was conducted at the end of a period when political parties, including Kadima, made gains by highlighting their 'centrist' credentials. After a shift in the Israeli governing coalition after the 2009 elections, it may have become more popular to present as 'left-wing' to mark opposition to the Netanyahu-led government, rather than as a specific indicator of favouring the Peace Camp or a socialist model of economic redistribution. Finally, perceptions about my identity - as a non-Israeli, non-Jewish researcher, based in Europe, at a time when political criticism of Israel was high in Europe - also seemed to play a role in recruitment, with more self-identified 'leftists' actively volunteering. Self-identification as 'left' was not always confirmed when the detail of opinions was probed. We should bear in mind that Jewish-Israeli designations of political identity not only vary based on what is being discussed (Occupation or socio-economic issues) but also are relative to what Somer calls the relative political centre in any given political context. I used snowball and random-purposeful criterion sampling to find additional right-wingers and centrists, and their responses are appropriately weighted in the analysis.

\section{Notes}

1 Regarding ensuring rigour, trustworthiness, authenticity and credibility in an interpretivist research paradigm: Denzin and Lincoln, Handbook.

2 Moustakis, Phenomenological. Laverty, "Hermeneutic."

3 Whittemore, Chase and Mandle, "Validity."

4 Patton, Qualitative.

5 Creswell, Five Approaches. Emmel, Sampling. Miles and Huberman, Qualitative.

6 Moustakas, Phenomenological.

7 Almog and Almog, Snowflake?

8 Yadgar, Traditionists.

9 On combining these two methodologies: Annells, "Triangulation."

10 Kuckartz, Qualitative.

11 There are many smaller constituencies which defy any religious right/secular left binary: datim (Orthodox Jews) who critique Israel's security regime in the West Bank on religious grounds; haredim (ultra-Orthodox Jews) whose critique of the Zionist state overlaps somewhat with hiloni leftist critiques of the Occupation; or hilonim who vote for Jewish Home along with Orthodox and some traditional Jews.

12 Day, "Researching Belief."

13 Jong, Halberstadt and Bluemke, "Foxhole Atheism."

14 Yadgar, Traditionists.

15 Portelli, "Oral History." 